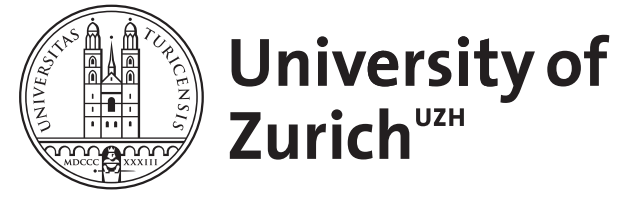

\title{
A Plea for a "Behaviorist" Approach in Writing the History of Medicine
}

Ackerknecht, Erwin H

DOI: https://doi.org/10.1093/jhmas/xxii.3.211

Posted at the Zurich Open Repository and Archive, University of Zurich ZORA URL: https://doi.org/10.5167/uzh-154221

Journal Article

Published Version

Originally published at:

Ackerknecht, Erwin H (1967). A Plea for a "Behaviorist" Approach in Writing the History of Medicine. Journal of the History of Medicine and Allied Sciences, XXII(3):211-214.

DOI: https://doi.org/10.1093/jhmas/xxii.3.211 


\title{
A Plea for a "Behaviorist" Approach in Writing the History of Medicine
}

\author{
ERWIN H. ACKERKNECHT*
}

Tor long ago my collaborator, Dr. Hans Walser, discovered that 1 in the Franco-Prussian War of $1870-71$ many amputations were performed without the benefit of anesthesia ("Der Krieg und die Aerzte"). This observation shocks us somewhat, in view of the fact that general anesthesia had been introduced successfully, according to our textbooks, a quarter of a century before. Our surprise is only possible because the medical history we read and write today is still based mostly on the writings of an élite of medical men. We are primarily students of scientific literature. Excellent as this may be, it teaches us relatively little concerning what this élite actually $d i d$, and even less of what the average physician or surgeon did. Since our contemporaries in consultative practice are well aware of the gap which even now exists between the medicine preached and the medicine generally practised, and since studies are available which reveal the width of this gap in the goth century, it is time that historians looked hard at the actualities of the past.

Probably most of us have encountered in the course of our research other examples illustrating this gap in our knowledge. Many of our misconceptions are due, of course, to the fact that we think in terms of the present and tend to underestimate the time span extending between an invention and its general acceptance and application in times gone by, the famous "lag" of the sociologists. But as a short review of my own "surprises" seems to show, several other forms of ignorance are involved in addition.

My own somewhat oversimplified concepts were first seriously shaken when I found out (see Ackerknecht, E. H. Malaria in the Upper Mississippi Valley, Baltimore, 1945, pp. 115 ff) that despite $P$. Louis and Marshall Hall's proofs of the negative effects of bleeding (ca. 1830) the habit began to recede seriously only in the 1870 os. (Cf. Leon C. Bryan, Jr. Blood-Letting in American Medicine, 1830-1892. Bull. Hist. Med., 1964, 28, 516-29.) Study of the catalogues of medical supply houses issued around the turn of the century not only support this contention, but reveal an almost incredible number of ancient instruments still in use. While these

- Institute of the History of Medicine, University of Zürich, Zürich, Switzerland. 
are examples of "lag", the fact, e.g., that at the time of Portal only very few physicians were able to palpate successfully, or that Broussais, according to his adversary Velpeau, was in spite of his theories a successful therapist can not be explained this way. (Ackerknecht, Medicine at the Paris Hospital, 1794-1848, Baltimore, 1967.)

My collaborator, Dr. Otto M. Marx, found contradictions between therapeutic advice of $19^{\text {th }}$ century psychiatric treatises and the actual practices of their authors as described in medical travel literature so pronounced that he is now making a special study of this travel literature.

We must admit to ourselves that we often do not know the most elementary facts of either medical practices or of the social aspects of medical practice even for periods not very far removed at all. How high a percentage of the population was seen by a doctor a hundred years ago? (O. Esser: Der praktische Arzt im Rheinland, $175^{0}-185^{\circ}$, unpublished thesis, Bonn, 1963 , P. 49, gives some amazing figures on this.) How many of those doctors who publicly condemned mesmerism or homoeopathy used it? When and how did treatment by correspondence come to an end? Who knew till Wuetherich's recent publication that uroscopy was practised widely by German practitioners up to the 18 gos? ("Das Ende der Uroskopie.") What were the real practices of those who, in Europe, actually treated the great mass of the population up to the middle of the last century, the surgeons and apothecaries? Even the most intensive preoccupation with the writings of court physicians, academicians or university professors will never answer this crucial question.

We know very little of the history of the precepts of medical ethics, though A. Nussbaumer's recent thesis on the Stahlian, Johann Storch (Zürich, 1965) has considerably added to our knowledge in this direction. We know even less to what extent these rules were applied. We do not know exactly when the honorarium was replaced by the fee. In spite of George Rosen's pioneer effort (Fees and Fee Bills, Baltimore, 1946) we know little of the history of fee bills and "tariffs." We know even less of what the different kinds of healers actually received.

M. H. Koelbing has recently drawn attention to the fact that around 1890 Paris was still full of "ambulant oculists" (Médecine et Hygiène, 1964, 22, 925-6). George Rosen's excellent pioneer study, "The Specialisation of Medicine" (New York, 1944), has unfortunately not been continued by other scholars searching in the same direction. 
Henry E. Sigerist undoubtedly alluded to these gaps in our knowledge, when he wrote ( $A$ History of Medicine, New York, 1951, vol. I, p. 14): "The history of medicine, however, is infinitely more than the history of the great doctors and their books. Medical science is important, but it is wasted unless its findings are applied on a large scale. ... We therefore must pay attention to the history of the rank and file doctor and the other medical workers." But his time ran out before he could give us his results in this direction. Th. Puschmann, F. H. Garrison, and P. Diepgen (in his chapters on "Das ärztliche Leben") have probably been, so far, those medical historians who in their treatises have paid most attention to these problems, but their discussions remain extremely fragmentary. When some more recent books have touched upon them, like, e.g., The Midwest Pioneer by M. E. Pickard and R. C. Buley (New York, 1946), they have unfortunately remained too much on the anecdotal level, a common defect of this type of study. But E. S. Turner's Call the Doctor (London, 1958) shows that even such an "anecdotal" book can be quite useful.

I should be completely misunderstood if what I have said above were to be interpreted as a plea for abandoning the type of research we have been doing so far. This work remains essential, useful, and very, very far from being exhausted. We do not even have a thorough Galen study! Only, the older I get, the more I feel the necessity of additional studies to complete our picture of the past. And as researchers in the history of medicine fortunately grow more numerous, this should be feasible. It would be all the easier if medical historians would devote their efforts to different objects, and cease imitating, in their own way, the slaves of fashion in other fields. It is a somewhat melancholy sight to observe medical historians these days clustering around certain "great men", while others and other problems of equal importance, are passed by.

In order to answer questions like those raised above, other sources will, of course, have to be tapped. They are most of the time not as "brilliant" as the traditional sources, and often demand even more caution in their interpretation. But they do exist, in greater numbers than is often suspected, and they often have their own charm. There are, of course, above all, case histories, with data on treatment, which exist in profusion, especially after the 16 th century. Owsei Temkin's admirable pioneer study of the history of the case history (Kyklos, 1929, 2, 42-66) has unfortunately found no successors. We have already mentioned travel 


\section{Journal of the. History of Medicine: JuLY, 1967}

reports. We should also like to draw attention to the extensive pamphlet literature accompanying the medical reform movements in Europe around the middle of the $19^{\text {th }}$ century, "cahiers de doléance", as it were, of the medical profession. I once listed over 4oo such publications for Germany alone around 1848 (Sudhoffs Archiv, 1932, 25, 164-80). And such pamphlets are by no means rare for the $17^{\text {th }}$ or 18 th centuries. Medical periodicals or society transactions-I need only remind my readers of the early transactions of the A.M.A.-are full of relevant data. As a matter of fact, doctors have never suffered in silence. Governmental archives contain very enlightening reports. Diaries, autobiographies, or even contemporary novels, sometimes yield valuable information.

As everything seems to need a name, I would suggest calling the approach I am here pleading for the "behaviorist approach"-not in deference to the psychological doctrines of the late J. B. Watson, whose lack of interest in "conscience" revealed a one-sidedness and lack of understanding of the totality of reality similar to Karl Marx's contempt for the "superstructure"-but taken in its literal sense. In this sense the word "behaviorist" expresses rather well what I am aiming at: more extensive and more critical analysis of what doctors did in addition to what they thought and wrote. I am fully aware of the fact that the elements of the equation are, of course, very closely related. 